\title{
Organic Matter Removal from Piggery Wastewater in Waste Stabilisation Pond in Nigeria
}

\author{
1*OKORO, BU; ${ }^{2}$ NWAIWU, NE \\ ${ }^{1,3}$ Department of Civil Engineering, Nnamdi Azikiwe University, Awka, Nigeria
}

\begin{abstract}
Four (4) wastewater quality variables: chemical oxygen demand (COD), total solid (TS), total dissolved solid (TDS), and total suspended solid (TSS) were determined. Analysed samples comprises of raw influent and effluents entering and leaving the stabilisation ponds. Significant reduction in variables were obtained, maximum and minimum values obtained for COD were $917 \mathrm{mg} / 1$ (anaerobic pond), and 13mg/l (maturation pond). For TS, TDS and TSS, maximum and minimum values obtained were $14,420 \mathrm{mg} / \mathrm{l}$, 9,180mg/l, 5,240mg/l and 3,398mg/1, 3,120mg/l, 278mg/l respectively. Removal efficiencies recorded for parameters in final effluent (maturation pond) were $98.55 \%$ (COD), 76.44\% (TS), 66.01\% (TDS), and 94.69\% (TSS) respectively. (C) JASEM
\end{abstract}

\section{http://dx.doi.org/10.4314/jasem.v20i1.8}

KEYWORDS: Wastewater quality variables; reduction; removal efficiency; stabilisation pond

Introduction

The activities of man results in diverse kinds of waste materials that become waterborne and these wastes must be treated before released into the environment. Wastewaters contain excreta, household wastes, industrial wastes, agricultural runoffs, and waste from urban storm drainage which can pollute and contaminate the environment. Urbanization in Nigeria has led to a drastic increase in waste generation making control of wastewater increasingly difficult as can be seen in her surface and groundwater resources. Public health implications of untreated wastewater is enormous as most wastes emanating from household, agricultural farms and industrial processes are usually water borne and need be safely disposed of if the millennium development goal must be achieved; the conservation of water resources and the pollution level of the environment must be checked. To effectively dispose wastewater, an effective waste disposal technology must be adopted. Most of existing disposal systems in Nigeria such as septic tank, catch pits e.t.c are inefficient in detoxification of waste hence, the need for adopting a system that is environmentally suitable and cost effective.

A few waste stabilisation pond (WSP) exists in Nigeria which are used in treatment of domestic and industrial wastewater. Wsp have extensively been utilised in education institutions such as the Ahmadu Bello University, Zaria; Obafemi Awolowo University, Ile-Ife and University of Nigeria, Nsukka and a few industrial and housing estates for domestic wastewater treatment. These ponds have been discovered to operate below efficiency; the design population for most of the ponds has long been exceeded which results in serious overloading problems $[2,12]$.

Biological treatments of domestic and industrial wastewaters have increased tremendously, because they have been found to be appropriate for most developing nations, where land and labour are still relatively cheap and the climate favour natural degradation of organic matters [13]. Consequently, biological treatment of these wastewaters requires a combined process of carbon and nitrogen removal [13]. The high occurrence of sunlight in Nigeria and lack of adequate facilities for maintenance of complex mechanical systems, make WSP very suitable for the Nigerian environment. Agunwamba [1] expressed that, unlike in the developed countries where properly structured maintenance and monitoring programs for WSP system are practiced; ponds in Nigeria are neither monitored nor properly maintained. 
Many of the WSP systems in use in Nigeria are in poor state and some virtually dried up and almost covered by bush. The sides of the ponds are eroded in many places, blockages of wastewater pipes, large fluctuations in the quantity and quality of the effluent and reduction in the strength of influent sewage - all due to inadequate and irregular water supply- are frequent. Treatment of agricultural waste is a major environmental aspect that has been neglected in the country for decades now which has led to incessant dump of these waste on land and water ways thereby aiding pollution and public health concern. Absence of existing research on treatment of agricultural waste has aided this research study and this will make available information regarding the efficiency of treatment system in containing waste of farm origin.

\section{MATERIALS AND METHODS}

Analytical Procedures: Description of Laboratory Setup: Piggery waste for piloting research work was collected from a piggery located in Awka, Anambra state, Nigeria. The temperature of study area is high throughout the year averaging from $27^{\circ} \mathrm{C}$ to $34^{\circ} \mathrm{C}$. The waste is collected comprises of raw influent which is the solid/ semi- solid waste obtained from the piggery and spillage water from drinkers, veterinary activities impacted waste, e.t.c

Wastewater generated from a piggery was utilized for the laboratory experiment. Based on the results obtained from the measured samples and design parameters, a laboratory-scale pond will be constructed. A field scale prototype of a WSP was designed and rescaled to a laboratory-scale model using Froude number and dimensional analysis. The ponds are three in number namely: anaerobic (1 No.), facultative (1 No.) and maturation ponds (1 Nos.). A laboratory-scale unit (Figure 1) was operated in a batch mode by adding manure effluent daily under prescribed flow rates.

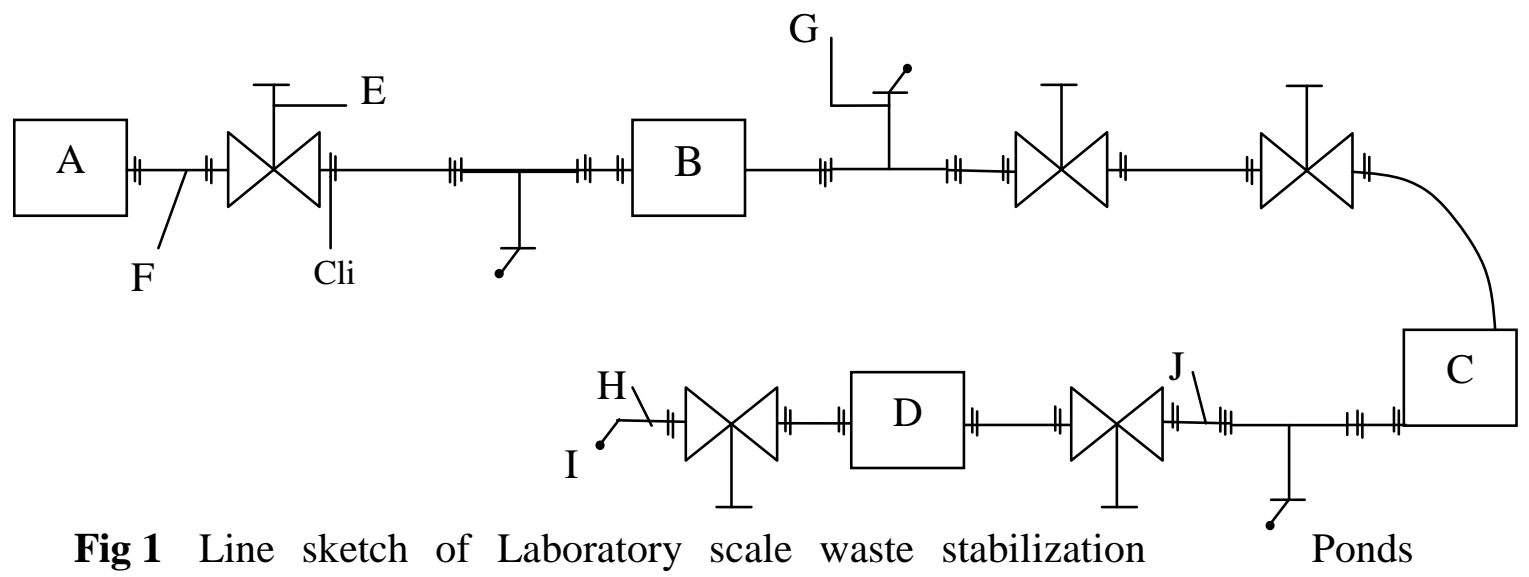

A - Equalization basin B - Anaerobic pond C - Facultative pond D - Maturation pond E - 12.7mm gate valve $\mathrm{F}-12.7 \mathrm{~mm}$ pipe $\mathrm{G}-12.7 \mathrm{~mm}$ Tee $\mathrm{H}$ - Socket $\mathrm{I}-12.7 \mathrm{~mm}$ Plastic Tap J - Nipple

Physicochemical Parameters Analysed: challenges encountered in laboratory methods

Samples results (especially for $\mathrm{BOD}_{5}$ ) obtained from commercial laboratory had some controversies in terms of the method used. As at the time of conducting research experiment, the laboratories within the university community lacked capacity to carry out the tests; these was attributed to unpreparedness and erratic power. Effort was made in informing commercial laboratory about identified errors which was acknowledged but wasn't corrected. Due to controversy in $\mathrm{BOD}_{5}$ result obtained from commercial laboratory (due to very low value recorded that doesn't represent the true nature of piggery wastewater), supervisor advised adoption of COD value in place of BOD.

Chemicals and Solvents: Analytical grade (A.R.) chemicals were utilized during course of experiment work. Laboratory in-house distilled water was used in all procedures requiring the use of water. 
Total Suspended Solids (TSS) The method defined by Shrivastava et al. [16], and Awasthi et al. [5] has been used to determine TSS.

$$
\text { TSS }=\text { TS-TDS }
$$

Total Dissolved Solids (TDS) The method defined in Standard Methods i.e. APHA 2510 A TDS 139 tester [3] have been utilized to evaluate TDS [5, 16]. 50ml of sample was filtered through a Whatman filter paper (Whatman type $\mathrm{GF} / \mathrm{F}$ $0.45 \mu \mathrm{m})$. Filtrate was allowed to evaporate to dryness, stored in desiccators to cool.

Calculation:

$\mathrm{TDS}=\frac{(\mathrm{A}-\mathrm{B}) \times 10^{3} \mathrm{mg} / \mathrm{l}}{\text { Sample volume in } \mathrm{ml}}$

Where $\mathrm{A}=$ weight of dish + solids (mg) $\mathrm{B}=$ weight of dish before use $(\mathrm{mg})$

Determination of Total Solids: Total solids is the term applied to the material residue left in the vessel after evaporation of the water sample and its subsequent drying at a temperature of 103$105^{\circ} \mathrm{C}$. Total solids include Total Suspended Solids and Total Dissolved Solids [4]. Procedure involves measuring $50 \mathrm{ml}$ of the water samples into a pre-weighed dish and evaporated to dryness at $103^{\circ} \mathrm{C}$ on a steam bath. The evaporated sample was dried, cooled in a desiccator and recorded for constant weight.

Chemical Oxygen Demand Pisarevsky et al. [15] defined chemical oxygen demand (COD) as a measurement of pollution in terms of the total concentration of substances that can be chemically oxidised in the water. $15 \mathrm{ml}$ of the wastewater sample was added to a $250 \mathrm{ml}$ beaker and was refluxed with an accurate unknown amount of a potassium dichromate $(2.5 \mathrm{ml}$ standard $5 \% \quad \mathrm{KCrO}_{4}$ digestion reagent), slowly mixed in a large excess of sulphuric acid $(3.5 \mathrm{ml}$ of conc. Sulphuric acid reagent was introduced slowly through sides of the beaker) for a definite time to oxidise most of organic substances. Remaining dichromate was determined by titration with ferrous ammonium sulphate. Beaker was capped and content mixed before transfer into a water bath alongside a blank also. Distilled water was added to make up volume to $50 \mathrm{ml}, 2-3$ drops of ferroin indicator was added and titrated with $0.05 \mathrm{M}$ ferrous ammonium sulphate (FAS) solution (mohr salt). The COD was calculated from the relation:

$\mathrm{COD}=\frac{(\mathrm{A}-\mathrm{B})}{\mathrm{ml} \text { of sample }} \times \mathrm{M} \times 8000$

\section{RESULTS AND DISCUSSIONS}

Chemical Oxygen Demand (Cod) RemovalInThe Wsps: Measurement of COD for the six retention times in the WSPs is shown in Figure 2 and Figure 3. Highest value of COD measured in the anaerobic pond for 5 day retention time was $917 \mathrm{mg} / \mathrm{l}$ and concentration obtained on termination of retention time was $459 \mathrm{mg} / \mathrm{l}$. Removal efficiency of COD in anaerobic pond is possible with influence of bacteria [14]. In this pond, the heterotrophic activity in facultative and maturation pond is much more pronounced here as compared to photosynthetic processes.

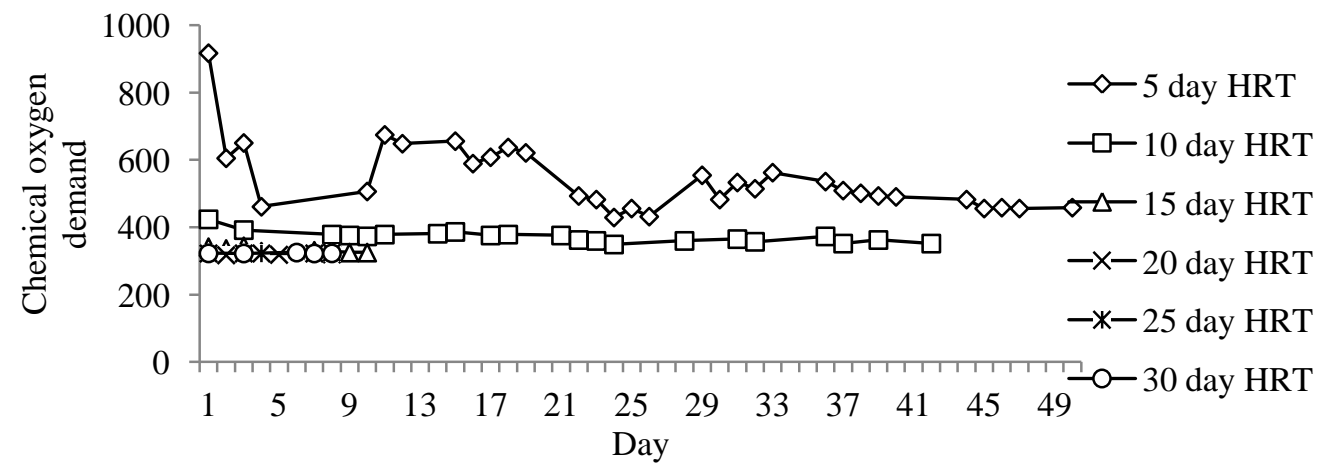

Fig 2 Chemical Oxygen demand (COD) variations at different retention times in Anaerobic Pond 
The COD reduction in the facultative and maturation pond was much more evident compared to reduction in the anaerobic pond. In the facultative and maturation pond, COD values on inception of 5 day retention time was $643 \mathrm{mg} / \mathrm{l}$ and $563 \mathrm{mg} / \mathrm{l}$; flow between these ponds were actually established after high COD and nutrient level have been stabilized in the anaerobic pond operating at same retention time. Concentration obtained on $18 / 5 / 2015$, the termination time for the 5 day retention time was $315 \mathrm{mg} / \mathrm{l}$ and $189 \mathrm{mg} / \mathrm{l}$ for the facultative and the maturation ponds respectively. These experimental observation tallies with results of other researchers who noted a reduction of $75-90 \%$ COD removal in WSPs $[10,18]$.
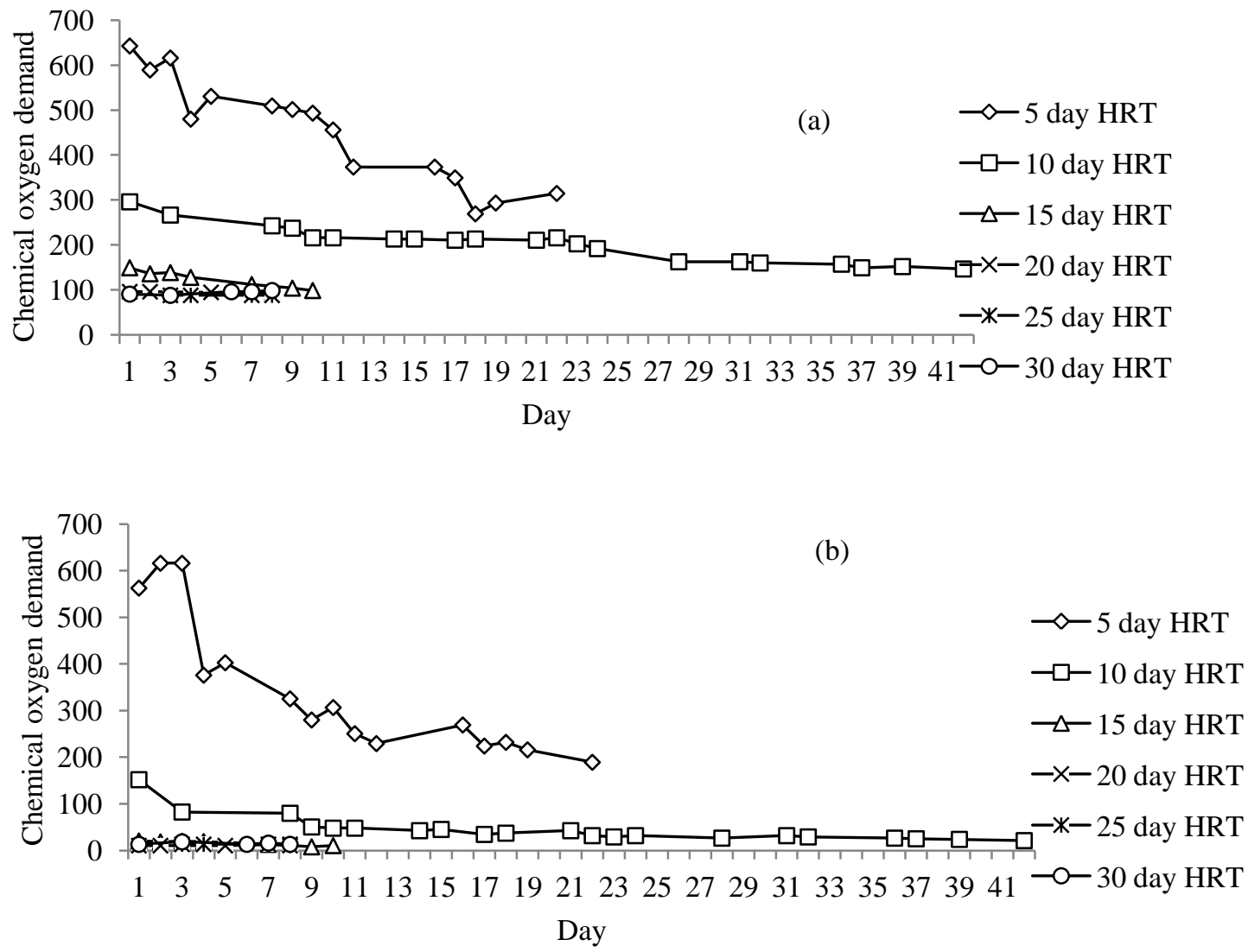

Fig 3 Chemical Oxygen demand (cod) variations at different retention times in (a) facultative and (b) Maturation Pond

Removal efficiency of COD: Removal of COD in anaerobic pond was for the various retention times were $50 \%, 61.63 \%, 64.24 \%, 65.12 \%, 64.53 \%$ and $64.80 \%$ for the $5,10,15,20$ and 25 day retention times respectively. Facultative pond removal efficiencies were noted to be $65.70 \%, 84.01 \%$, $86.05 \%, \quad 89.83 \%, \quad 90.41 \%$, and $89.24 \%$; maturation pond's was $79.36 \%, 97.67 \%, 97.91 \%$, $98.55 \%, 98.84 \%, 98.55 \%$, for the $5,10,15,20,25$ and 30 day retention times respectively. 
Table 4. Removal Efficiency of COD in Anaerobic, Facultative and Maturation Ponds

\begin{tabular}{cccccccc} 
Parameter & Ponds & \multicolumn{6}{c}{ Hydraulic Retention Time (day) } \\
\cline { 3 - 8 } & & 5 & 10 & 15 & 20 & 25 & 30 \\
COD & Anaerobic & 50.00 & 61.63 & 64.24 & 65.12 & 64.53 & 64.80 \\
$(\mathbf{m g} / \mathbf{L})$ & Facultative & 65.70 & 84.01 & 86.05 & 89.83 & 90.41 & 89.24 \\
& Maturation & 79.36 & 97.67 & 97.91 & 98.55 & 98.84 & 98.55 \\
\hline
\end{tabular}

The best efficiency as was recorded for the anaerobic pond was the 25 day retention time. In the facultative pond, best pond removal efficiency was $90.41 \%$ during the 25 day retention time, and for the maturation pond, it was also 25 day retention time $(98.84 \%)$. All ponds recorded a removal efficiency greater than $50 \%$, which shows a good efficiency of removal. Removal efficiency in waste stabilization has been reported to be above $90 \%$ [10] as further confirmed by efficiency of treatment ponds.

\section{Removal of Solids}

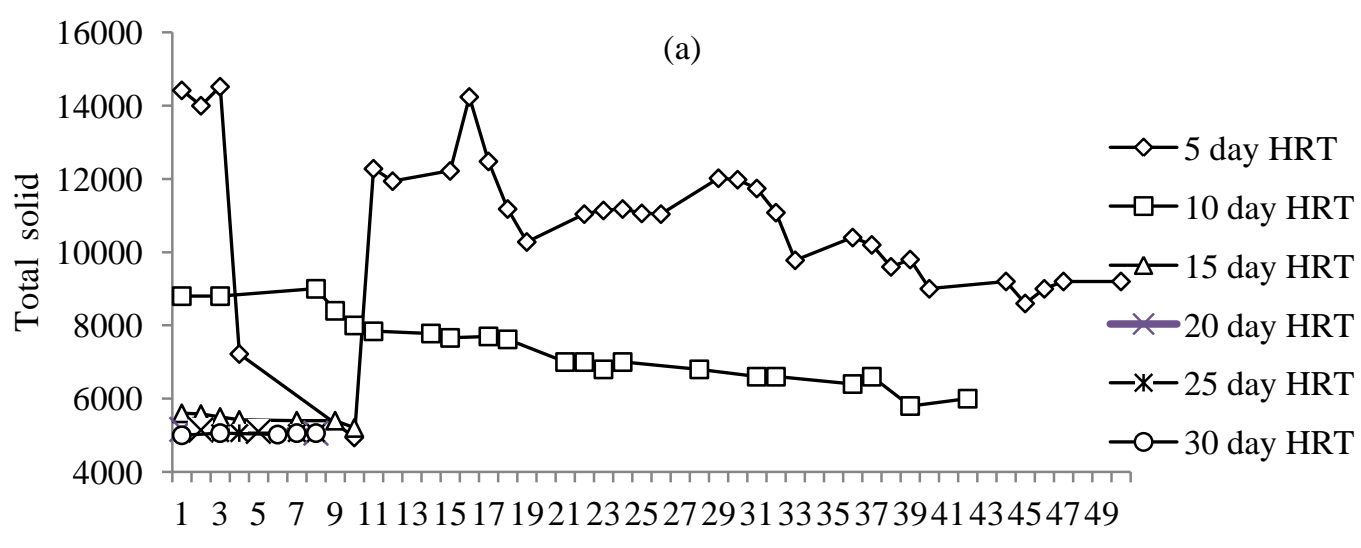

Day

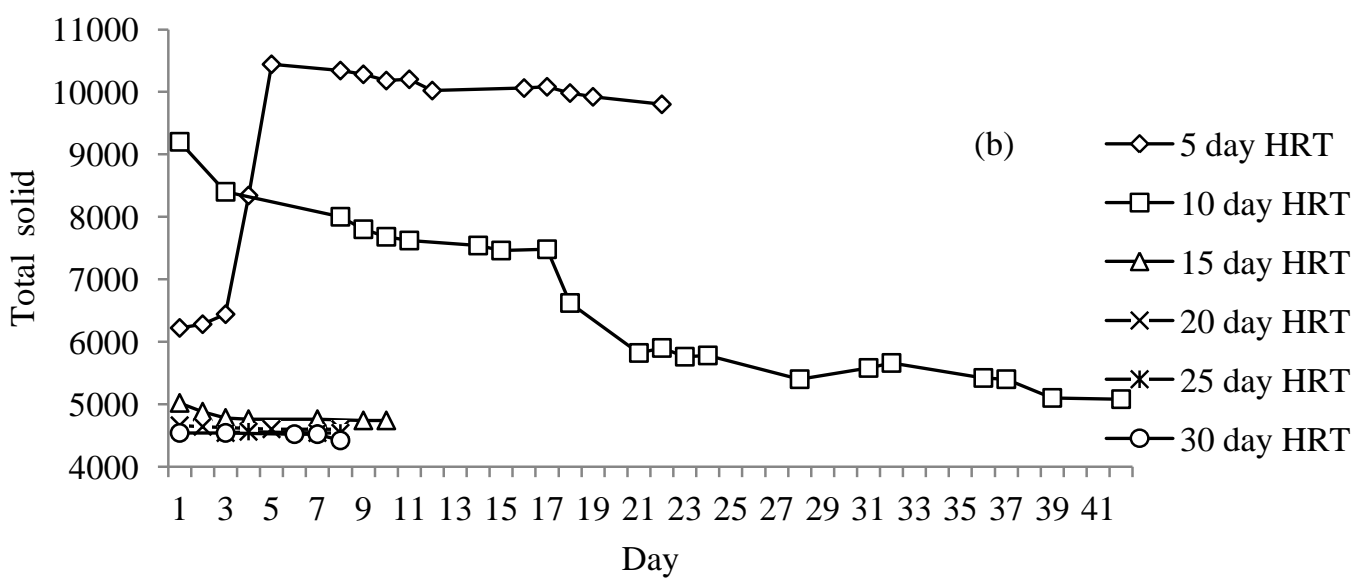

Fig 4 Total Solid variations at different retention times in (a) Anaerobic Pond and (b) facultative Pond
Solids removal during wastewater treatment is of great importance. High solid concentration in wastewater increases density of wastewater and reduces oxygen solubility which can affect growth of algae and other organisms in ponds that aids in waste remediation processes [6]. Total solids concentrations in wastewater for the six retention times are shown in Figure 4 and Figure 5. Concentration of TS in anaerobic pond for the 5 day retention time showed a maximum value of $14420 \mathrm{mg} / \mathrm{l}$ at the influent point and $9200 \mathrm{mg} / \mathrm{l}$ during sampling on the $18 / 5 / 2015$ (last sampled concentration for the 5 day retention time). 

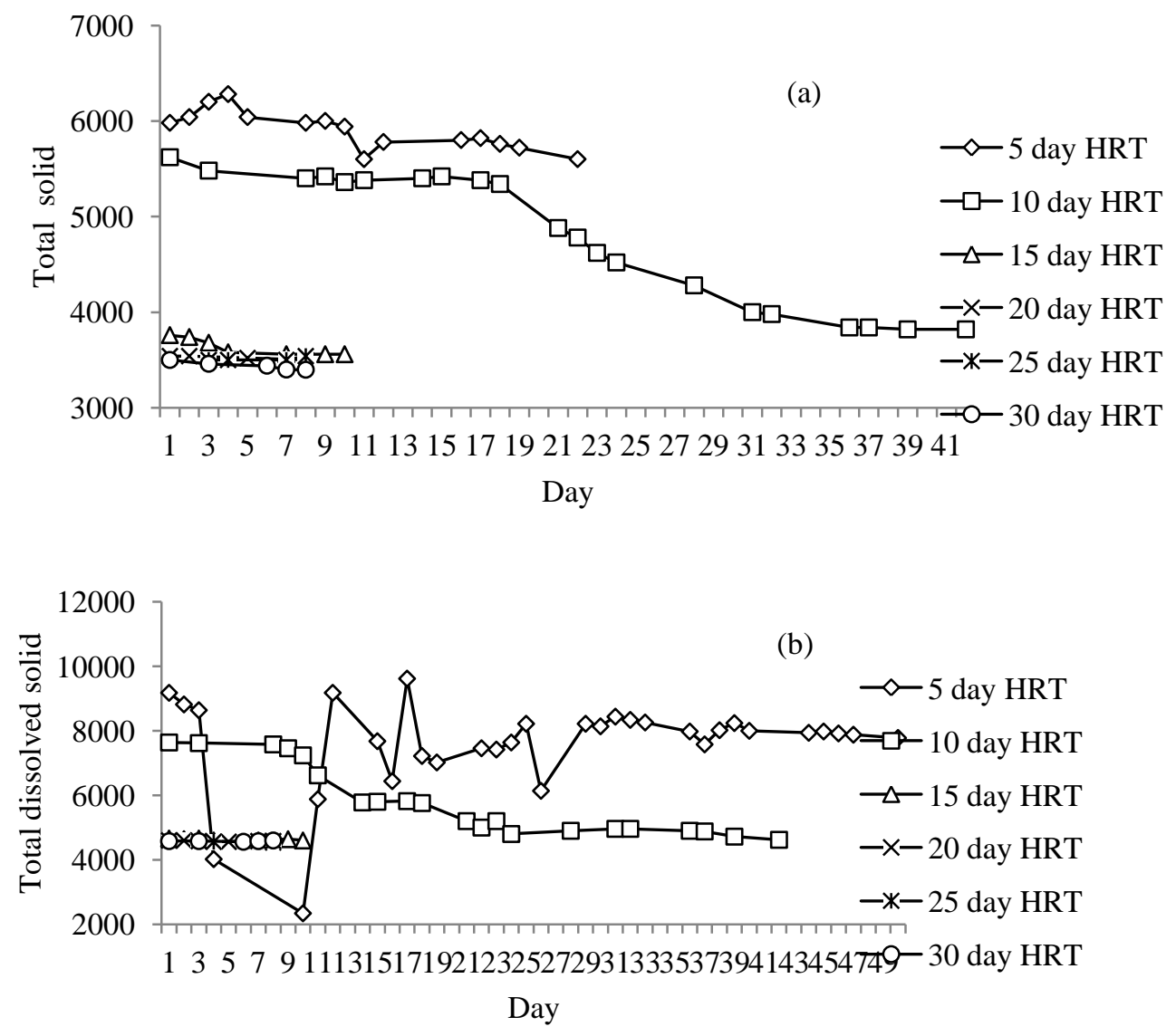

Fig 5 (A) Total Solid variations at different retention times in Maturation Pond and (b) total dissolved solid variations at different retention times in Anaerobic Pond

A substantial amount of solids was removed in the anaerobic pond. However, solids removal in the facultative pond during the 5 day retention time was characterized by a corresponding rise in value of TDS which could be attributed to entrant of solids into the facultative pond from anaerobic.
The anaerobic pond may be said to have experienced a complete mix process, gas bubbles production was evident and was periodically rising from the bottom of the pond to the top during the retention time of $5-20$ days. 

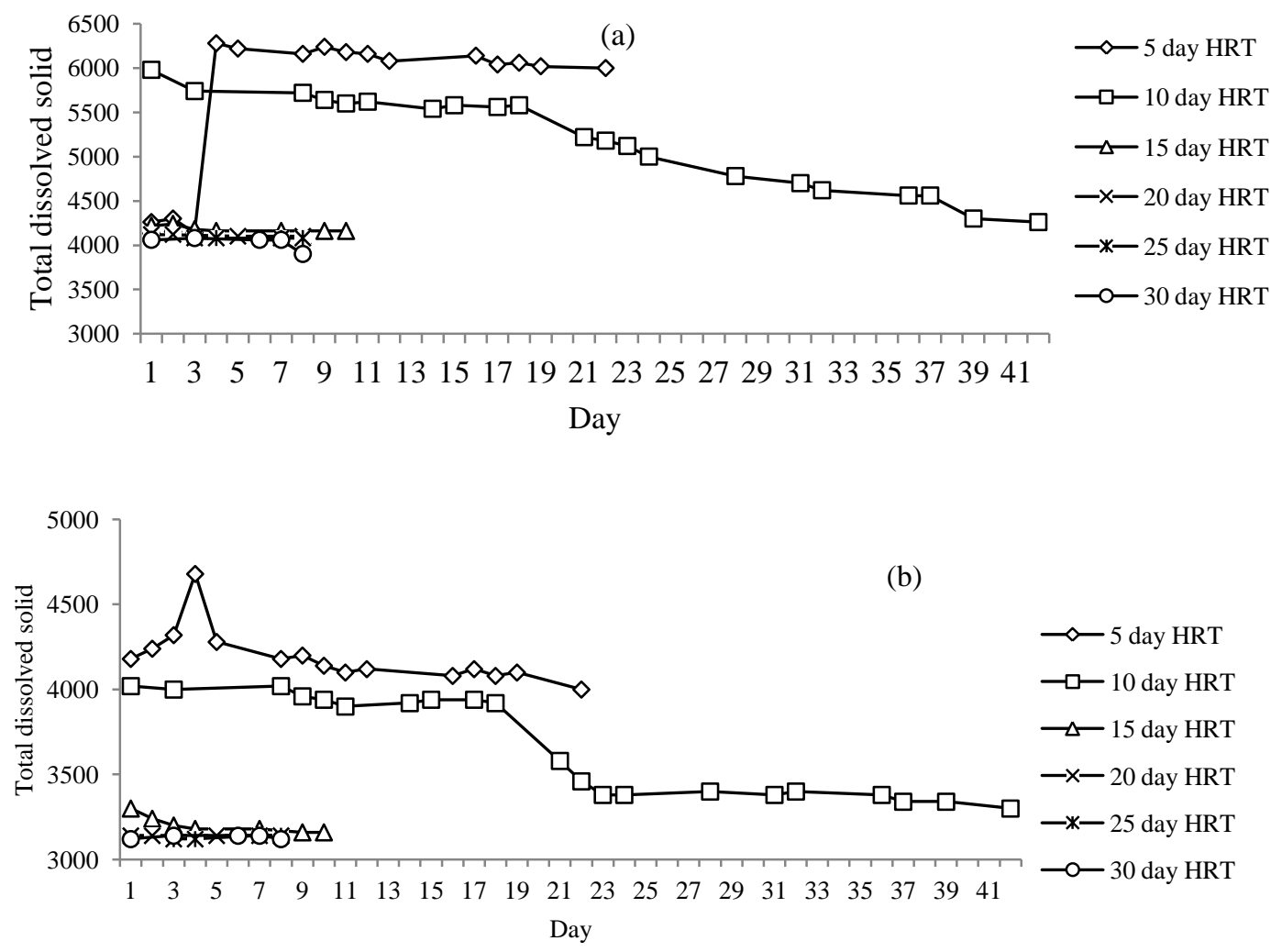

Fig 6 total dissolved solid variations at different retention times in (a) facultative Pond and (b) Maturation Pond

Moreno [11] observed similar behavior in anaerobic ponds in Iran during study to ascertain efficiency of treatment of pond adjacent to Isfahan, these phenomena impacted on result of SS. WHO [17] further noted that dissipation of gases like $\mathrm{CO}_{2}, \mathrm{CH}_{4}$ and $\mathrm{H}_{2} \mathrm{~S}$ in waste stabilization ponds in temperate regions, causes settled materials rise from bottom of pond to the surface leaving the pond in the effluent; this impacts dearly on quality of effluent as depicted in anaerobic and facultative ponds in Figures 4, 5, 6,7 , and 8 . Other ponds in laboratory setup mimicked the plug flow behavior as feeding of wastewater was semi- continuous. Removal of solids in WSPs was below the recommended limit. The poor solid removal as observed in the anaerobic pond may be attributed to nutrient and carbon recycling of sludge [9]. To reduce or eliminate incidences of re-suspension of solids in ponds, installation of screens will greatly aid the removal of grit in the equalisation basin and subsequently in the anaerobic pond.

Suspended solids exceeding recommended limit in effluent can cause environmental hazards ranging from inhibiting penetration of sunlight to physical harm of fishes [8]. Heavy metals precarious to human health can get attached to suspended solid which may be absorbed by irrigated plants thereby posing as threat to human health. High TDS level in effluent can lead to decreased hydraulic conductivity of irrigated lands leading to rapid drop in crop production [7]. 


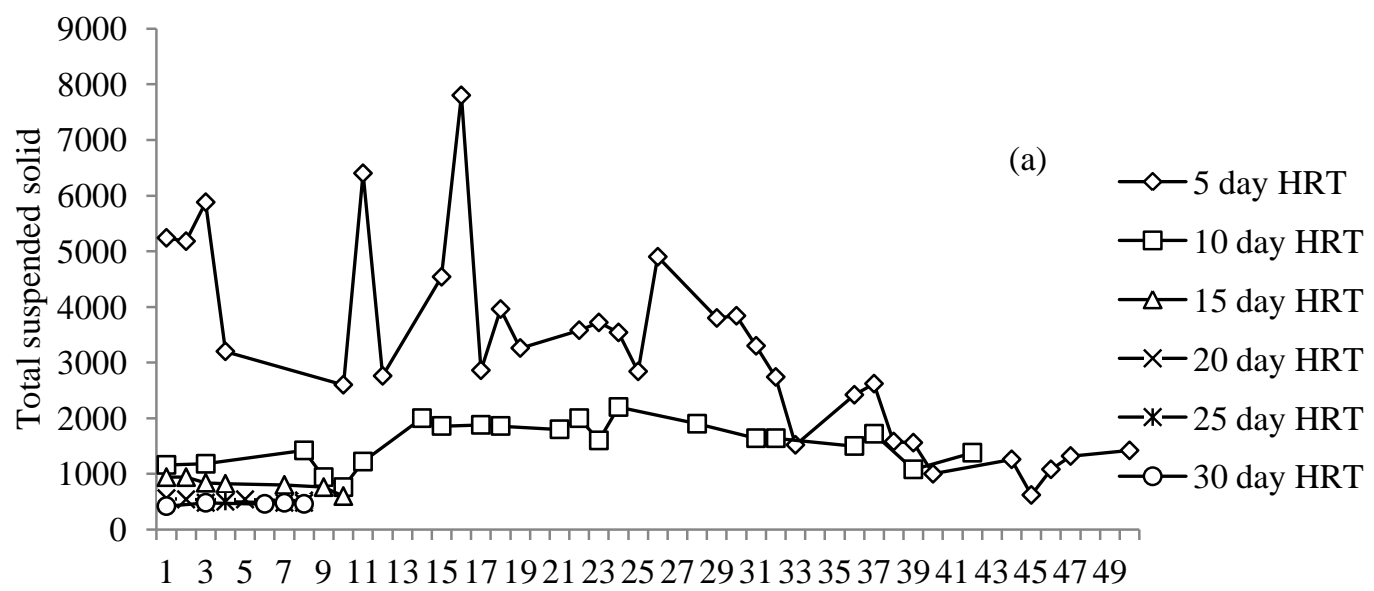

Day

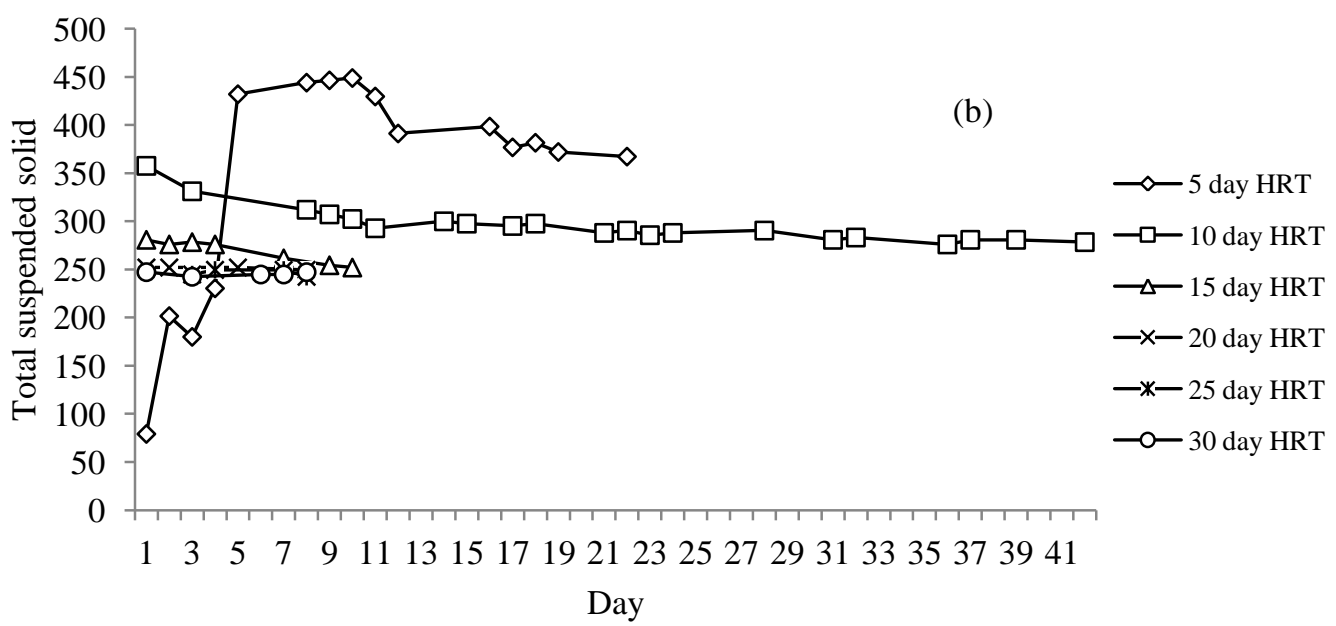

Fig 7 Total suspended solid variations at different retention times in (a) Anaerobic Pond and (b) Facultative Pond

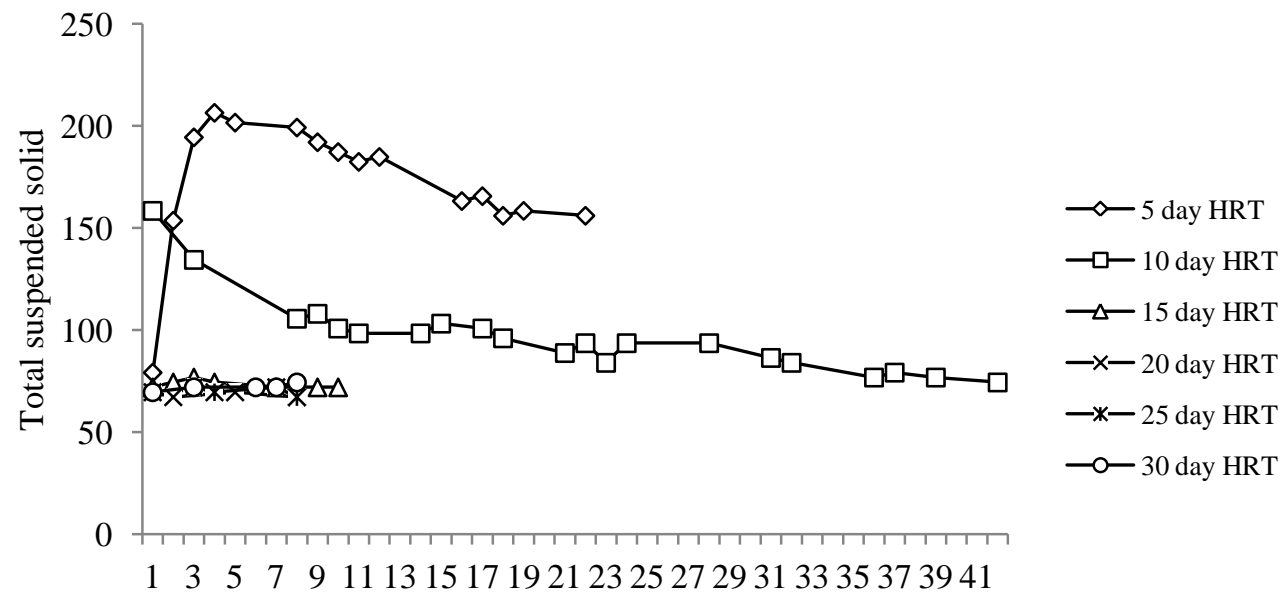

Day

Fig 8 Total suspended solid variations in maturation pond at different retention times 
Removal efficiency of solids: The efficiency of solids from the WSPs as shown in Table 4.5, shows that total solid (TS) in anaerobic pond were: $36.20 \%, 58.39 \%, 62.41 \%, 64.91 \%, 64.91 \%$ and $64.91 \%$, total dissolved solids (TDS): $15.2 \%$, $49.67 \%, 49.89 \%, 50.4 \%, 50.11 \%, 49.89 \%$, total suspended solid (TSS): 72.90, 73.66\%, 84.35\%, $90.08 \%, 90.84 \%, 91.22 \%$ for the $5,10,15,20$ and 25 day retention times respectively. TS in the facultative pond were noted to be $32.04 \%$, $64.77 \%, 66.99 \%, 68.10 \%, 68.52 \%$, and $69.35 \%$;
TDS value were $34.64 \%, 53.59,54.68 \%, 55.34 \%$, 55.56 and $57.52 \%$ while TSS were $27.48 \%$, $84.35 \%, 88.55 \%, 90.46 \%, 91.22 \%$ and $90.08 \%$; in the maturation pond, TS values were $61.17 \%$, $73.51 \%, 75.17 \%, 75.73 \%, 75.45 \%, 76.44 \%$; TDS was $56.43 \%, 64.05 \%, 65.36 \%, 65.80 \%, 65.80 \%$, $66.01 \%$ while the value for TSS were $69.47 \%$, $90.08 \%, 92.37 \%, 93.13 \%, 92.37 \%$ and $94.69 \%$ respectively for the $5,10,15,20,25$ and 30 day retention times respectively.

Table 4.5 Removal Efficiency of solids in Anaerobic, Facultative and Maturation Ponds

\begin{tabular}{lrrrrrr}
\hline \multicolumn{1}{c}{ Parameter/ } & \multicolumn{7}{c}{$\mathbf{5}$} & $\mathbf{1 0}$ & $\mathbf{1 5}$ & $\mathbf{2 0}$ & $\mathbf{2 5}$ & $\mathbf{3 0}$ \\
\cline { 2 - 7 } HRT (d) & \multicolumn{5}{c}{ Anaerobic pond } \\
TS & 36.20 & 58.39 & 62.41 & 64.91 & 64.91 & 64.91 \\
TDS & 15.25 & 49.67 & 49.89 & 50.54 & 50.11 & 49.89 \\
TSS & 72.90 & 73.66 & 84.35 & 90.08 & 90.84 & 91.22 \\
& & \multicolumn{5}{c}{ Facultative pond } \\
TS & 32.04 & 64.77 & 66.99 & 68.10 & 68.52 & 69.35 \\
TDS & 34.64 & 53.59 & 54.68 & 55.34 & 55.56 & 57.52 \\
TSS & 27.48 & 84.35 & 88.55 & 90.46 & 91.22 & 90.08 \\
& & \multicolumn{7}{c}{ Maturation pond } \\
TS & 61.17 & 73.51 & 75.17 & 75.73 & 75.45 & 76.44 \\
TDS & 56.43 & 64.05 & 65.36 & 65.80 & 65.80 & 66.01 \\
TSS & 69.47 & 90.08 & 92.37 & 93.13 & 92.37 & 94.69 \\
\hline
\end{tabular}

The best efficiency of removal recorded for TS, TDS and TSS was during 20 day retention time (anaerobic pond), 30 day retention time (facultative pond) and 30 day retention time

Conclusion: Wastewater of piggery origin was analysed and found to contain a high concentration of organic matter which was further subjected to treatment in a laboratory scale waste stabilisation pond to determine the extent of removal of organic matter and solid content in it. Result reveals that removal efficiencies of $98.55 \%$ (COD), $76.44 \%$ (TS), $66.01 \%$ (TDS), and $94.69 \%$ (TSS) respectively can be obtained in the treatment technique which shows that treatment ponds utilised for piggery waste treatment under tropical condition operates well despite inability to reduce below permissible limit total solid and total dissolve solid, overall system performance was appreciable. (maturation pond). Poor efficiency of removal as observed in anaerobic ponds were due to mixing pattern earlier recorded, this impacted greatly on the pond's efficiency.

\section{REFERENCES}

Agunwamba, J.C. Desludging interval in a waste stabilization pond: a markov approach. Journal of Environmental Management, 1993; 38:289-299.

Agunwamba, J.C. Effect of tapering on the performance of waste stabilization ponds. Wat. Res, 2001; 35(5):1191-1200.

APHA. Standard methods for the examination of water and wastewater, $2^{\text {nd }}$ edition. APHA, Washington D.C, 2005.

APHA. American Public Health Association Standard Methods for the Examination of Water and Wastewater, APHA, New York, NY, USA, 2012; 22nd edition.

Awasthi, S.; Jain, K.; Das, A.; Alam, R.; Surti, G.; Kishan, N. Analysis of food quality and food adulterants from different departmental \& local grocery stores by qualitative analysis for 
food safety. IOSR-JESTFT 2014; 8(2): 2226

Bangash, F.K.; Fida, M; Fazeel, A.T. Appraisal of effluents of some selected industries of Hayatabad industrial estate, Peshawar. J. Chem. Soc. Pak; 2006; 28(1): 16-19

Bouwer, H. Groundwater Hydrology. McGrawHill Company, New York, 480

Horner, R.R; Skupien, J.J; Livingstone, E.H; Shaver, H.E. Fundamentals of urban runoff management. Technical and Institutional Issues, Terrene Institute, Washington, DC, 1994.

Mbwele, L.A. Microbial phosphorus removal in waste stabilisation pond wastewater treatment systems. Thesis, Royal Institute of Technology: Stockholm; 2006.

Moez Bouali, M.; Zrafi, N.I.; Bakhrouf, A.; Le Paslier, D.; Chaussonnerie, S.; Ammar, E.; Sghir, A. Appl. Microbiol. Biotechnol. 2012; 465: 435-436.

Moreno, M.D. A tracer study of the hydraulics of facultative stabilization ponds. Water Research, 1990; 24(8): 10251030

Oke, I. A; Akindahunsi, A. A. A statistical evaluation of methods of determining BOD rate, Journal of Applied Science Research, 2005; 1(2): 223-227.
Oke, I. A.; Otun, J. A.; Adie, D.B. An assessment of selected methods in environmental pollution controls. Journal of Food, Agriculture \& Environment, 2009; 7 (1):186-191.

Picot, B.; Andrianarison, T.; Gosselin, J.P.; Brissaud, F. Twenty years' monitoring of Mèze stabilisation ponds: part I - removal of organic matter and nutrients. Water Scince and Technology. 2005; 51(12): $23-31$.

Pisarevsky A.; Polozova I.; Hockridge P. Chemical oxygen demand. Russian journal of applied Chemistry. 2005; 78(1): 101-107

Srivastava, K. K.; Ahmad, N.; Kumar, D.; Das, B.; Singh, S. R.; Lal, S.; Bhat, S. K. Influence of diverse pollen source on compatibility reaction and subsequent effect on quality attributes of sweet cherry. African Journal of Agricultural Research, 2013; 8(3): 262-268.

WHO "Waste Stabilization Ponds", WHO, Emro Technical Publication, 1987; No 10, Alexandria, Egypt.

Zimmo, O.R.; Vander, S.N.P; and Gijzen, H.J. Nitrogen mass balance across pilot-scale algae and duckweed-based wastewater stabilization ponds. Water Research. 2004; 38:4, 913-920. 